\title{
ISLAM IN PROVINCIAL INDONESIA: Middle Class, Lifestyle, and Democracy
}

\author{
Noorhaidi Hasan
}

State Islamic University Sunan Kalijaga Yogyakarta, Indonesia

\section{Abstract}

Islamic symbols have flourished in the public spaces of Indonesian provincial towns after Subarto. This phenomenon has occurred in parallel with the significant shifts in the social, economic and political fields, which is tied to the mounting impact of Islamization, social mobility, economic growth, and democratization occurring among town people. It is as if we see a parallel move between Islamization, modernization, globalization and democratization. Key concepts associated with these trends are appropriated with those rooted in tradition and local culture to inform the whole dynamics of Indonesian provincial towns today. The key player in this process is the new middle class, who look to Islam for inspiration both to claim distinction and social status and to legitimize their consumptive lifestyle. They are newly pious who act as active negotiators between the global and the local as well as the cosmopolitan centre and the hinterland. They also play a pivotal role as an agency that liberalizes religion from its traditionally subservient, passive and docile posture by turning it into a source of moral legitimacy and distinction to represent a modern form of life. Given its intimate relationship with locality, tradition, modernity as well as globalization, Islam has increasingly assumed a greater importance for local politics. Political elites have used Islamic symbols for the instrumental purpose of extending their political legitimacy and mobilizing constituency support, in a political environment of open competition and increased public participation in decision making. In this process religious symbols have irrefutably been distanced from their religious moorings and narrow, Islamist understandings, in favor of pragmatic political purposes. 
Keywords: Islamic symbols, middle class, globalization, lifestyle, local politics

\section{A. Introduction}

In parallel with the rapid process of globalization Indonesia has seen major transformations. These include a greater sense of autonomy for both men and women, and the emergence of a public sphere in which politics and religion are subtly intertwined. Mass education and mass communication have facilitated an awareness in Muslims of the need to reconfigure the nature of religious thought and action, create new forms of public space, and encourage debate over meaning. Within this context Islam has become the subject of dialogue and civil debate. Open contests over the use of the symbolic language of Islam and its meanings have increasingly shaped this new sense of public space that is discursive, performative, and participative. The appearance of "public Islam" in the Muslim world has coincided with the emergence of a new middle class which involves itself in the debates about objectifying Islam. This class is mainly distinguished by the capacity of its individuals and households to accrue surplus income, beyond that needed for the necessities of life. Their rising demands for a more nuanced lifestyle led them to adopt Islamic symbols as a mode of modern cultural expression in public spaces. Islamic symbols provide a sense of legitimacy and moral value for members of the new middle class, and a means by which its members' social identities are formed.

The trend of metropolitan, urban, middle class Indonesians adopting Islamic symbols to claim distinction and moral legitimacy for their consumptive lifestyle has resonated through Indonesian Islam, and profoundly impacted the dynamics in provincial towns. Due to the development of massive infrastructure and the advancement of mass communication, the boundaries of big cities and provincial ones have become increasingly blurred. Trends that develop in the big cities easily progress to provincial ones. However, these trends do not just develop. They are not only adapted and used in appropriation with the local context, but also modify and are modified in turn by pre-existing trends in the provincial towns. The process of appropriation also involves agency, acting to determine the form of Islam that will prevail in the provincial 
town's public spaces. The role of the middle class has been crucial as an agency facilitating the burgeoning of a new form of market-friendly piety, which accepts the idioms of modern democracy. It is noteworthy that the familiarity of society with its roots and culture also demands a strong legitimacy from history and culture itself. This is because institutional symbols of traditional religion often resurface and require affirmation from religious actors, who in turn, have sought sources of legitimacy in their effort to offer Islam in provincial public spaces.

This paper is aimed at analysing the changing landscape of Indonesian provincial towns marked by the mushrooming of religious symbols that has occurred in tandem with the emergence of a new middle class which has become aware of the importance of religious identity for their social status and lifestyle. It looks at the extent to which Islamization has gained a foothold and the peculiar modernization it produced. One of the most salient features of the relation between tradition and modernization in provincial town life is Islam's location at the centre of town values and activities. It constitutes the most pivotal point in the complex dynamics of the negotiation between tradition and modernity. This paper thus also examines the way in which the middle class plays a pivotal role as an agency facilitating the growth of public Islam in provincial Indonesia where ideas about locality, tradition, modernization and globalization as well as ideas about Islam's significance for town public life are mutually reinforcing. Finally, it looks at the extent to which Islam has contributed to the recent dynamics of local politics in Indonesia.

\section{B. Islamization in Town}

In a country like Indonesia, in political, economic, cultural, and administrative matters, the town plays an intermediary role between the cosmopolitan centres and the hinterland. It serves as a meeting point and mediator between the outward-reaching national (and global) culture, institutions, and processes on the one side and the increasingly selfassertive agricultural village majority on the other. Unlike cosmopolitan centres, where there is greater sociocultural differentiation, towns seeks to manage tension between the global and the local more smoothly. The tension is often more explicit than that in the cosmopolitan centres, but it is held in check by cross-cutting personal ties. The global is spread 
through modern political, education, economic and cultural institutions. Its legitimacy is however bolstered by means of the assimilation of key concepts associated with the global with tradition and local culture. Looking at Indonesia from provincial towns allows us to understand how the local, the cosmopolitan, and the global have intertwined in informing multiple manifestations of the complex relationship between the political, the economic, the social, the cultural and the religious.

This is not ungrounded theory. It does not take many minutes of conversation to start to see how provincial towns seek to manage tension between the global and the local by means of appropriation and harmonization. This phenomenon is evident in Kebumen, the market and administrative centre for a district bearing the same name, located in the southern part of Central Java. This town has vast hectares of lush paddy fields that yield around 150,000 tonnes of rice per year. Ironically, based on the data from 'penerima bantuan langsung tunai (BLT)' literally translated as the 'recipients of direct cash assistance', in 2007, 46 percent of its population still lived in poverty. When I carried out research for this paper in 2007-2008, Kebumen was led by district head (Bupati) Rustriningsih and her deputy, Nashiruddin al-Mansur. It was the fourth poorest kabupaten (regency) of the 35 regencies and cities of Central Java. In addition, more than 17,000 people were illiterate and 13,957 children aged between 7 and 15 years were not enrolled in school. The school drop-out rate was also very high. It has been reported that more than 66,000 people have not completed their primary education. The high numbers of illiterate people and school dropouts explain why 96,024 families in Kebumen (or 30.43 percent) are classified as 'pre-prosperous' and 75,052 families (23.78 percent) are in the socio-economic status group 'pre-prosperous 1'. More shockingly, 35,311 people, from a total of 315,591 people in the productive age group, were unemployed. The high unemployment rate is correlated with the fact that a huge number of Kebumen workers have migrated for greener pastures abroad. ${ }^{1}$

Despite its claimed status as a santri town (kota santri) with 99 percent of its population being Muslims, Kebumen had never strongly supported Islamic parties. No Islamic party had won a majority since the

${ }^{1}$ For a comparison, see the annual report by the Regional Development Planning Board of Kebumen, Kebumen dalam Angka 2006 (Kebumen: Bappeda, 2006). 
first elections in 1955. However, kyai, traditional 'ulama in Java, do have an important cultural influence in Kebumen. The latest data show that the district has 121 pesantren, traditional Islamic boarding schools led by kyai. These religious leaders have long held a special position in the Kebumen community, as reported by sociologist, Jennifer Alexander, during her observations in the 1980s. Her research primarily examined economic development, and took place in a district located to the east of Kebumen. She concluded that Clifford Geertz's characterization of Javanese society as being divided into santri, abangan and priyayi groups was not relevant in Kebumen. Geertz's santri group practice orthodox Islam, while the abangan population practice a more syncretic, Javanese flavoured version. The priyayi are drawn from the traditional Javanese aristrocratic class, and often hold responsible administrative positions. According to Alexander, in Kebumen people tended to reject the santri/abangan distinction and the trichotomy santri/abangan/priyayi. They generally pictured themselves as Muslims with a firm commitment to Indonesian nationalism. ${ }^{2}$ Unlike other orthodox santri, who stress the formalization of religious expression and the pursuit of piety and orthopraxy, the majority of the population Alexander described were able to strike a compromise between Islam, traditional values and indigenous culture.

Kebumen is probably better pictured as a place where IslamicJavanese moderate practices prevail and abangan beliefs are still alive. The military has described several isolated districts in Kebumen as 'red spots', once under Communist influences. Kebumen has also been described as a 'tinderbox', or a place where both the political extreme left and extreme right can both be found. In 1950, a religious rebellion exploded in Kebumen as a consequence of rationalization within the body of the Indonesian Republic Armed Forces. This rebellion was led by a local militant leader, Machfudz Abdurrahman, the owner of the Al-Kahfi Islamic boarding school in Sumolangu and more popularly known as Kyai Sumolangu. He refused to merge with 'The Lemah Abang Battalion' formed by the army. Instead, he formed his own battalion known as the Chimayatul Islam. Unfortunately negotiations between the Kyai and the army ended in disagreement, and as a result a confrontation with the

2 Jennifer Alexander, Trade, Traders and Trading in Rural Java (Singapore: Oxford University Press. 1987), p. 16. 
army was inevitable. ${ }^{3}$ Given this historical peculiarity, the highest political position in Kebumen was always reserved for army officials.

Only recently have Islamic forces and secular power reached a point of convergence in Kebumen. A huge billboard in front of the regent's official residence on Kebumen's main square shows Rustriningsih wearing a trendy colourful headscarf. Her (male) deputy Nashiruddin wears a green turban. Islamic symbols have replaced Javanese insignia as the tools of political communication. Islamic nuances are being strikingly incorporated into the bureaucratic sphere elsewhere as well. As is occurring at the national level, more and more female civil servants in Kebumen are wearing headscarves and becoming involved in regular religious activities organised by the region's government units. Arabic maxims promoting efficiency and transparency are scattered around the walls of local government offices. The increasingly conspicuous religious symbols in Kebumen's public places reflect the sustained penetration of Islamic orthodoxy into the heart of this abangan culture and its attempts to move towards full integration as part of a modern, globalizing Indonesia.

As in other mid-sized Javanese towns, Islamic proselytising ( $\left.d a^{\prime} w a\right)$ groups have grown more active in Kebumen over the years. Young people are at their core. Their goal is to formalise religious expressions and introduce a more orthodox version of Islam into Kebumen society. Notable among them are the Hidayatullah group, which is under the auspices of al-Iman Foundation, and the PKS, which coordinates the Ibnu Abbas, the Perempuan Muslimah, and the Iqra Club Foundation. Both groups set up education institutions and introduced what they call integrated-Islamic schools, in which the younger generation of Muslims are taught to internalize the principle of Islam's totality. These schools are founded on the belief that the future of Indonesia lies in the commitment of Muslim youth to consistently follow the example of the Prophet Muhammad and the first generation of Muslims ( Salaf al-Salih - pious ancestors). ${ }^{4}$ One impact (among many) of the $d a^{\prime} w a$ activities organized

${ }^{3}$ Several degree holders believe that AUI has connections with Gerakan Pemberontakan DI/TII (Rebellion Movement) that is led by Kartosuwirjo. For more information on AUI, please refer to Singgih Tri Sulistiyono, Pemberontakan Angkatan Umat Islam (AUI) di Kebumen 1950 (Semarang: Mimbar, 2000).

${ }^{4}$ Interview with Muhammad Yunus and Abdullah Munir, the Chairman of alIman Foundation and the Headmaster of SDIT al-Madinah respectively, Kebumen, 
by the Iqra Club is that 90 per cent of female students at SMU 1 and SMK 1, Kebumen's preferred senior high schools, now wear headscarves. The penetration of the new da'wa groups was not totally unexpected. Mainstream Muslim groups, such as NU and Muhammadiyah, had long expressed concern about the weak religiosity and domination of abangan culture in isolated villages in several of Kebumen's sub-districts, such as Sempor, Buayan, Karangsambung, and Mirit. Although many 'ulama and religious teachers were aware that the new ultra-orthodox da'wa groups might challenge their established religious practices and give new expression to their faith, they generally welcomed them as partners in the struggle for the glorification of Islam (syi'ar Islam) throughout Kebumen. They even acknowledged the creativity of the way they packaged Islam to make it more attractive to the broader Kebumen (or more precisely abangan) community. ${ }^{5}$ Fear of the way these new da'wa groups have expanded has only recently surfaced as a public concern. The catalyst was their systematic campaign to infiltrate schools, many of which belonged to Muhammadiyah, to recruit Muhammadiyah youths into their cause. A number of the Muhammadiyah faithful openly challenged the expansion of puritan da'wa into their education institutions, in Kebumen town itself as well as in its sub-districts of Gombong, Kutowinangun, Sadang, Pejagoan and Karanganyar. ${ }^{6}$

The growth of Islam's public visibility can also be seen strikingly in Martapura, the capital town of Banjar regency, which is located 40 $\mathrm{km}$ to the north of Banjarmasin, the capital city of South Kalimantan province. This regency is divided into 17 sub-regencies with 288 towns and villages. Since its establishment in 1950, the Banjar regency's head has changed 16 times. The current district head is Khairul Shaleh, and his running mate is Muhammad Hatim Salman. According to 2006 statistical data, the total population was 464.148 , comprised of 238,162 men and 225,986 women. The most densely populated area was the district capital, Martapura, with 2,042 people per square kilometre. School participation

17 October 2007.

${ }^{5}$ Interview with Bambang Purwanto, Islamic teacher and staff at the Regional Department of Religious Affairs in Kebumen, Kebumen, 16 October 2007.

${ }^{6}$ Interview with Muhammad Dahsyad, a member of the Education Council of Muhammadiyah in Kebumen, and Muhammad Abduh Hisyam, the Secretary of Muhammadiyah in Kebumen, 12 October 2007. 
has increased over time with increases in the number of schools. Currently there are 350 primary schools, 39 junior high schools, and 9 senior high schools under the auspices of the National Department of Education. The total number of students is 55,269. In addition to this, there are 217 schools at all levels under the Department of Religious Affairs, with 26,872 students. There are 459,124 Muslims, compared to 314 Protestants, 209 Catholics, 101, Hindus, and 98 Buddhists and others. Based on the same statistic data, there were 2,118 job applicants in 2006, many of whom held senior high school diplomas. From this number, 1,136 were reportedly absorbed in various job markets and positions. ${ }^{7}$

The close identification of Martapura with Islam can be traced back to its historical trajectory as the capital city of the Banjar Sultanate before the Dutch ruined it in the war of 1859-63. There, 'ulama (religious scholars) played a pivotal role in politics. Muhammad Arshad al-Banjari, a charismatic 'ulama in the nineteenth century, was the first Grand Mufti of the Banjar Sultanate, under Sultan Adam's rule between 1825 and 1857. As Grand Mufti he integrated the shari'a into the political structure of the Banjar Sultanate, and was responsible for issuing the Sultan Adam Law (Undang-Undang Sultan Adam) stipulating application of various aspects of the shari' $a$, especially the ritual (ibada) and the social contract (mu'amala), in accordance with Shafi'ite legal doctrines. This historical trajectory explains the identity of Martapura as a town that prides itself on being the 'front porch of Mecca' in Kalimantan. ${ }^{8}$ In addition to this, close identification of Martapura with Islam has much to do with the self-image of the Martapuran Muslims, who portray themselves as a pious, pleasant and polite society, thus different from the other Banjarese clan groups, especially from Upper River (Hulu Sungai).

The presence of Islamic symbols in the town's public space was noticeable during Abdul Madjid's leadership of the Banjar regency in the mid-1990s. The Cahaya Bumi Selamat (CBS, the Light of Saved Earth) was built on the site of the town square, which had long provided a

${ }^{7}$ Interview with Ahmad Rabbani, staff at the Regional Development Planning Board of the Banjar regency. See also the annual report by the Regional Development Planning Board, Kabupaten Banjar Dalam Angka 2006 (Martapura: Pemkab Banjar, 2006).

${ }^{8}$ Rudy Ariffin, "Martapura Bumi Serambi Mekkah," in Nurhudianto (ed.), Martapura Bumi Serambi Mekekah, Secunting Pemikiran Rudy Ariffin (Martapura: Pemkab Banjar, 2004), pp. 33-5. 
community public space for Martapuran society. CBS is a jewellery trading centre. The vast building is in the architectural style of the Middle East, and at its centre a huge monument stands tall, complete with beautiful Arabic calligraphy. The overall effect is that of a magnificent, stunningly beautiful palace. It is a prestigious project intended to enhance the image of Martapura as a town built on jewellery, as well as the front porch of Mecca. The image of Middle-Eastern architecture dominating the main landscape of the Martapura town clearly illustrates the deep penetrating forces of Islam. During the time of Abdul Madjid's leadership, the Sekumpul Religious Study Group emerged and rapidly grew to become a religious, political, economic, and social magnet for Martapuran society and Muslims in South Kalimantan in general. This study group was founded in the early 1990s by Zaini Gani, better known as Guru Zaini, a charismatic cleric who decided to move from his old residence in Keraton sub-district to live in Sekumpul. At that time Sekumpul was a quiet, desolate area, full of karamunting trees. The presence of Sekumpul is emblematic of the growing importance of Islam in Martapura's public sphere. As a provincial town located outside Java which sees itself as marginalized in the highly centralized national development, Martapura has drawn strength from Islamic symbols to reinforce its local identity, and thereby negotiate its position in the face of the central government.

Realities after $9 / 11$ have led many observers to see the sprouting of religious symbols in the public spaces of Indonesian provincial towns as indicative of the success of Islamism in changing the whole landscape of Indonesian Islam. Largely defined as the political discourse and activism that aims to Islamize the secular system of society and state by exploiting religious symbols and identities, Islamism is perceived as posing a serious challenge to the existing secular democratic system of Indonesia and even spreading the threat of terrorism. The same observers imagine a bleak future for Indonesia, one that may be no different from Pakistan or even Iraq today, countries that are gradually being sucked into a maelstrom of political and religious violence. Obviously, this sort of alarmist perspective has failed to capture the dynamics and realities occurring in post-Suharto Indonesia, where the mushrooming of religious symbols is also coupled with the rise of a new middle class and the growth of democracy. This new reality is characterised by flourishing 
political activities based on electoral politics within the framework of a democratic system. Despite criticism from some sceptics who still judge Indonesia's emergent democracy as superficial, based on the assumption that it remains procedural rather than functional, and driven by political money and manipulation, one cannot deny that the electoral democratic system evolving in Indonesia today is rooted in the opening of political opportunity bolstered by certain levels of social mobility, economic growth, and broader participation in education and politics. The driving force behind this phenomenon is the middle class who, particularly in the context of Indonesian provincial towns, act as negotiators between the global and the local as well as the cosmopolitan centre and the hinterland. In their attempts to boost their identity and social status, the middle class is at the forefront in calling for the compatibility between Islam and modern values such as democracy, tolerance, and human rights, thus playing a significant role in the process of Islamization and democratization as well.

\section{Middle Class and Lifestyle}

Earlier debates on Indonesia's middle class paid scant attention to Muslim groups, but recognized their existence as one of the drivers of change, together with the entrepreneurial and professional intermediate groups and the officer corps. However given the antagonistic relations between Suharto's New Order and Islam, Muslim groups tended to be excluded from the circles privileged to benefit from this change, circles which included entrepreneurs, professionals and military political managers. These groups shared a common interest not only in preserving their acquired comfort and status, but also in restraining Islamic political claims. ${ }^{9}$ Historically speaking, Islamic political forces had long been the

${ }^{9}$ Daniel S. Lev, "Intermediate Classes and Change in Indonesia: Some Initial Reflections," in Richard Tanter and Kenneth Young, eds, The Politics of Middle Class Indonesia (Clayton, Australia: Centre for Southeast Asian Studies, 1990), pp. 25-43. Lev's analysis received a critical remark from Liddle who saw growing interests among the larger modern urban business persons and professionals of various kinds as well as urban lower classes such as rich rice farmers, producers of various agricultural commodities and even devout Muslims to trade their dependence for a larger share of the benefits of state largesse. See R. William Liddle, "The Middle Class and New Order Legitimacy: A Response to Dan Lev," in Richard Tanter and Kenneth Young, eds, The 
main opponent of the bureaucracy, standing on the front line to challenge secular power. ${ }^{10}$

The failure of Islamic political forces to make Islam a formal part of the state system served as a catalyst for the emergence of a Muslim middle class, centred around professionals, civil servants, intellectuals, and military officers. ${ }^{11}$ They came from santri-priyayi families, in the Geertzian paradigm, who sent their sons and daughters to modern schools and through this route propelled them into various economic bureaucratic sectors. In this way they became professionals in both state and private companies, expert staff assisting government ministers, members of parliament, director generals, heads of sub-directorates and many other strategic positions in the bureaucracy. This process of embourgeoisement or priyanization, in Aswab Mahasin's term, led the santri professionals to see Islam no longer as an alternative to the existing system, but rather as the inspirational base for a national, democratic framework for society. ${ }^{12}$ The inclusion of santri in the bureaucracy and civil services in turn contributed to the New Order's marked shift toward accommodating Islam in politics, shown by Suharto's personal support for the establishment of the Association of Indonesian Muslim Intellectuals (ICMI, Ikatan Cendekiawan Muslim Indonesia) in 1990. As a consequence of these changes in Indonesia's political environment, Muslim political groups have increasingly become the main patrons of the state, complete with a 'greening' process in the House of Representatives and the cabinet. From within the state system the Muslim middle class struggled to give Islam a central role in politics by repudiating the goal of an Islamic state, mobilizing ecumenical religious support, promoting women's rights and

Politics of Middle Class Indonesia (Clayton, Australia: Centre for Southeast Asian Studies, 1990), pp. 49-58.

${ }^{10}$ See Allan Samson, Islam and Politics in Indonesia (Berkeley: University of California Press, 1972); see also Kuntowijoyo, "Serat Cebolek dan Mitos Pembangkangan Islam: Melacak Asal-Usul Ketegangan antara Islam dan Birokraso," Ulumul Qur'an 5, 1 (1990), pp. 63-72.

${ }^{11}$ Abdurrahman Wahid, "Indonesia's Muslim Middle Class: An Imperative or a Choice?" in Richard Tanter and Kenneth Young, eds, The Politics of Middle Class Indonesia (Clayton, Australia: Centre for Southeast Asian Studies, 1990), pp. 22-24.

${ }^{12}$ Aswab Mahasin, "The Santri Middle Class: An Insider's View," in Richard Tanter and Kenneth Young, eds, The Politics of Middle Class Indonesia (Clayton, Australia: Centre for Southeast Asian Studies, 1990), pp. 138-144. 
championing Islam-based democratic ideals. ${ }^{13}$

Fluctuations in Islam's political relationship with the state inform both the dynamics and the formation of the Indonesian middle class vis-à-vis the state, making it difficult to identify the main characteristic of the class from a purely political perspective. The 'cultural capital' held by the middle class provides a foundation for the emergence of civil society associated with demands for representative space in political institutions. However, the middle class also has an interest in maintaining law and order, political stability and material prosperity, which may lead to their support for authoritarianism. ${ }^{14}$ Beyond political parameters, one can identify the Indonesian middle class by its performance in the public sphere and its consumer-based lifestyle. Dick reminded us of the importance of the mode of consumption as a defining characteristic of the Indonesian middle class. ${ }^{15}$ This argument seems plausible, since the 'mode of consumption' can be seen not only as a cultural representation of a class, but also a political statement. Consumption practices, though overwhelmingly apolitical in intent, have significant political consequences. ${ }^{16}$ To a large part the mode of consumption and

${ }^{13}$ Arif Budiman, "From Lower to Middle Class: Political Activities Before and After 1988," in David Bourchier and John Legge (eds.), Democracy in Indonesia 1950s and 1990s (Sidney: Centre of Southeast Asian Studies at Monash University, 1994), pp. 289-235; A. Syafi'i Anwar, Pemikiran dan Aksi Islam Indonesia. Sebuab Kajian Politike tentang Cendikiawan Muslim Orde Baru (Jakarta: Paramadina, 1995); see also Robert W. Hefner, Civil Islam, Muslim and Democratization in Indonesia (Princeton: Princeton University Press, 2000).

${ }^{14}$ Garry Rodan, "Theorising political Opposition in East and Southeast Asia," in Garry Rodan, ed., Political Oppositions in Industrializing Asia (London and New York: Routledge, 1996), pp. 1-39; see also Johan Saravanamuttu, "In There a Politics of the Malaysian Middle Class? in Abdul Rahman Embong, ed., Southeast Asian Middle Classes. Prospects for Social Change and Democratisation (Bangi: UKM Press, 2001), pp. 103-118. For the case of Indonesia, see Ariel Heryanto, "Indonesian Middle-Class Oppositon in the 1990s," in Garry Rodan, ed., Political Oppositions in Industrializing Asia (London and New York: Routledge, 1996), pp. 241-271.

${ }^{15}$ H.W. Dick, "The Rise of a Middle Class and the Changing Concept of Equity in Indoesia-An Interpretation," Indonesia 39: 71-91. This argument is repeated in his "Further Reflections on the Middle Class," in Richard Tanter and Kenneth Young (eds.), The Politics of Middle Class Indonesia (Clayton, Australia: Centre for Southeast Asian Studies, 1990), pp. 63-70.

${ }^{16}$ Ken Young, "Consumption, Social Differentiation and Self-Definition of the New Rich," in Michael Pinches, Culture and Privilege in Capitalist Asia, London: 
lifestyle of the educated urban middle class inspired the image of modern Indonesia promoted on the nation's television screens and through government broadcasts, and exemplified by the nation's leaders. The growth of the urban middle class itself is paralleled by the increasingly popular acceptance of consumer patterns associated with modernization. ${ }^{17}$

A sense of personalized Muslimhood has developed out of this context, which allows the middle class to demonstrate their religious identity through bodily purchased practices and goods. ${ }^{18}$ This model of Muslimhood is indubitably associated with their attempts to construct new narratives of themselves and their place in the world from creative blends of their own cultural inheritance and global influences. ${ }^{19}$ In the words of Göle, the Muslimhood model has enabled Muslims to experience the 'banalization process.' Actors from diverse backgrounds are involved in shaping the face of Islam in the public space and entering into the modern urban space with little hesitance. By using global communication networks they participate in public debates, track patterns of consumption and study the rules of the market, while at the same time embracing individualistic, professional and consumerist values. ${ }^{20}$

Seen from this perspective Islamic symbols seem significant to class mobility and the formation of the new middle class. In contrast to the old bourgeoisie, the new middle class, according to Bourdieu, no longer prioritizes the ascetic ethic of production and accumulation, but favours a morality of consumption based on credit, spending and enjoyment. They live in a social world driven by a new economy which

Routledge, 1999. p. 57.

${ }^{17}$ Patrick Guinness, "Local Society and Culture," in Hal Hill, ed., Indonesia's New Order. The Dynamics of Socio-economic Transformation (Honolulu: University of Hawaii Press, 1994), pp. 285-286.

${ }^{18}$ Jenny B. White, “The End of Islamism? Turkey's Muslimhood Model,” in Robert W. Hefner (ed.), Remaking Muslim Politics (Princeton, NJ.: Princeton University Press, 2005), pp. 87-111; Asef Bayat, Making Islam Democratic, Social Movements and the Post-Islamist Turn (Stanford, CA: Stanford University Press, 2007).

${ }^{19}$ Ariel Heryanto, "The Years of Living Luxuriously. Identity Politics of Indonesia's New Rich," in Michael Pinches, ed., Culture and Privilege in Capitalist Asia (London and New York: Routledge, 1999), pp. 159-187.

${ }^{20}$ Nilufer Göle, "Islamic Visibilities and Public Sphere," in Nilufer Göle dan Ludwig Ammann (eds.), Islam in Public Turkey, Iran, and Europe (Istanbul: Istanbul Bilgi University Press, 2006), pp. 3-43. 
judges people by their capacity for consumption, their standard of living and their lifestyle, as much as by their capacity for production. ${ }^{21}$ Bourdieu's scheme associates the new middle class with symbolic consumption and post-modernity. This allows us to investigate the new middle class's conception of lifestyle in relation to its habitus, and its concern to expand and legitimate its own particular dispositions and way of life. ${ }^{22}$ The nexus between habitus, consumption, and lifestyle proposed by Bourdieu is central to the new middle class's strengthening of its symbolic capital, with its promotion of cultural forms other than those enshrined in traditional middle class virtues, and thus its struggle with the traditional middle class. To be sure, in Bourdieu's quite distinct definition of class, cultural factors are seen to operate alongside economic ones.

As a matter of fact, the rising consciousness of the new Muslim middle class of the importance of Islamic symbols, with its willingness to engage in debate and objectify religion, looked to the availability of religious space within the urban landscape of metropolitan and big cities. In view of the growing demands for such space, government and business offices built mosques and musallas, small places to pray. Elite housing complexes and shopping centres provided meeting places for listening to public lectures on Islam (majlis ta lim). Convention centres and five star hotels advertised venues for religious programmes and Islamic study packages. Luxury Islamic centres, with a large mosque as the main building surrounded by training and education buildings, shops, and a hotel, have been built on large tracts of land in major cities like Jakarta, Surabaya, and Makassar. The new Muslim middle class comes to these places to engage in reciting the Qur'an, chanting dhikr (the profession of the faith), and the like, while discussing various aspects of Islam. In this way Indonesian Islam has experienced a process of gentrification, favouring global high-technology and consumerist Islamic appetites. ${ }^{23}$ While da'wa has somehow become urbanized, new creative agents and

${ }^{21}$ P. Bourdieu, Distinction. A Social Critique of the Judgement of Taste (London: Routledge and Kegan Paul, 1984), p. 310.

${ }^{22}$ M. Featherstone, "Lifestyle and Consumer Culture," in E. Meijer, ed., Everyday Life: Leisure and Culture (Tilburg: Department of Leisure Studies University of Tilburg, 1987), p. 158.

${ }^{23}$ Mona Abaza, "Markets of Faith: Jakarta Da'wa and Islamic Gentrification," Archipel 67 (2004): 173-202. 
young, popular preachers have emerged to work in both public and private settings. They offer a variety of innovative da'wa programmes which attract the interests of the new middle class.

The backdrop to this phenomenon was the Islamic revival that has swept across Indonesia since the 1980s, and has had a profound effect on the urban middle classes' rising demands for Islamic symbols as a mode of modern cultural expression in public spaces. ${ }^{24}$ Islamic symbols function as a source for middle class attempts to construct new narratives of themselves and their place in the world through practices of distinction. The distinctions made in different areas of everyday life are drawn from history, memory, friendship, consumption, and recreational practices; their inspirations come from multiple sources. The symbols themselves are subject to negotiation with the habitus of the class. In this way Islam has been transformed into a symbol of modernism and even elitism, and become part of a lifestyle. For instance the baju kurung (traditional modest attire of women) and mini telekung (outermost robe worn by women when praying), increasingly popular among Malaysia's Muslim middle class, are imbued with Islamic religiosity, whilst modesty, discipline and control are upheld. There is some experimentation here, symbolized by the exploration of mobility and gender identity of middle class Malay society. ${ }^{25}$ Being most forcefully subjected to intensified Islamic requirements, women developed "a strategic knowledge of dressing as a particular form of Islamic consumption, situated between public display of class and covering the body". ${ }^{26}$

A similar pattern of social differentiation is evident among the middle class in Martapura. Over time the fascination with Guru Zaini and the Sekumpul teaching complex has resulted in thousands of middle class people from Martapura town and other South Kalimantan cities migrating to the Sekumpul area. ${ }^{27}$ They built houses around the seven houses owned

${ }^{24}$ Moeflich Hasbullah, "Cultural Presentation of the Muslim Middle Class in Contemporary Indonesia,” Studia Islamika 7, 2 (2000), pp, 1-58.

${ }^{25}$ Johan Fischer, Proper Islamic Consumption, Shopping Among the Malays in Modern Malaysia (Copenhagen: NIAS Press, 2008), p. 79.

${ }^{26}$ Ibid., p. 82.

${ }^{27}$ Zain Alhakim, "The Sekumpul of 'Diamond' Master Teacher," in Asrori S Karni, ed., A Celebration of Democracy A Journalistic Portrayal of Indonesia's 2004 Direct Elections Amongst Moderate and Hardline Muslims (Jakarta: Era Media Informasi, The Wahid 
by Guru Zaini and his relatives, in the same row as the Al-Raudhah, the 'Kompleks Dalam Regol (Complex in the Archway). The Sekumpul complex has inspired the Martapuran community to engage in the cultivation of culture and social refinement. Trends made popular by the followers of the Sekumpul religious study group have a wide influence. The trends that originate and are developed there are taken up in Martapura and other towns in South Kalimantan. For instance, the trend for men to wear the koko shirt and the white kopiah (a kind of rimless cap), and for long dresses and colourful jilbabs for women originated at Sekumpul, has now become very popular in South Kalimantan. Sekumpul's role as a lifestyle trendsetter for South Kalimantan's provincial cities has evolved naturally.

Owning a home in the luxurious category in Sekumpul automatically privileges a person to become part of the Sekumpul community. The spatial and social distance between houses is very close, thanks to Sekumpul's TV, which features religious programs from the Dalam Regol. The TV programs helped everybody living in the houses strengthen their communal feeling as members of the Sekumpul society. These houses are alive with activity for four days of the week, particularly on Friday afternoons when people gather to follow the religious activities held in the Al-Raudhah. Except for caretakers, after these activities most people return to their respective towns and their daily routines as entrepreneurs, traders, civil servants and so forth. Some people stay permanently in Sekumpul, and partly due to Sekumpul some of these have been fortunate enough to develop extensive business networks, expanding the market for their products throughout Southern Kalimantan. People like Sarkani, Norhid, and Abdullah Assegaf have become successful businessmen in coal mining, the traditional Banjarese batik industry (sasirangan), precious stones and jewels and other large-scale business enterprises in South Kalimantan. ${ }^{28}$ Ismail Morsade is another succesful businessman living in Sekumpul. He was originally a Madurese enterpreneur from Sampit, Central Kalimantan, who decided to migrate to Sekumpul during the

Institute and the Asia Foundation, 2006), pp. 91-95.

${ }^{28}$ Alfisyah, "Agama dan Tingkah Laku Ekonomi Urang Banjar, Studi atas Pedagang Sekumpul Martapura Kalimantan Selatan," Unpublished MA Thesis (Yogyakarta: Universitas Gadjah Mada, 2005). 
bloody ethno-religious Madurese/Dayak conflict in the late 1990s. ${ }^{29}$ For Morsade, Sekumpul is not only a place to enjoy the overwhelming atmosphere of Islamic spirituality associated with Guru Zaini, who helped him overcome the emotional trauma of the conflict. It is also a place that offers socio-political-religious protection, and a promising area to develop his business activities in South Kalimantan. ${ }^{30}$

The religious symbolic meanings surrounding Sekumpul have seen prosperity flourish. Gradually, through its complex role at the intersection of multifaceted religio-political and economic activities, Sekumpul has come to be seen as as the 'kampung urang sugib' (village of the affluent) of South Kalimantan. As a spiritual market, Sekumpul is more than just a site for religious ceremonies and rituals. It has become a new source of religious and moral guidance. More importantly, it has also become a medium for religious middle-class consumers in South Kalimantan's towns to seek new identity and personal meaning - by consuming. At Sekumpul they can enjoy spiritual support from Guru Zaini, but after that they can shop for all the accessories and gadgets associated with the Sekumpul. Most people do not hesitate to spend millions of Rupiah for an exclusive Mushab Al-Quran (Qur'anic edition) signed by Guru Zaini, a Tasbih Fuqah (a type of rosary) or a Sekumpul-stamped Rihal Jati (a small teak table to put the Qur'an on). Many collectors buy the jilbab and kopiah haji sold in the Sekumpul. ${ }^{31}$ Slowly, Sekumpul has developed its own unique brand identity, sought after by its own middle-class market segment of loyal customers. Possessing Sekumpul merchandise and accessories allows a person to undeniably claim membership in Sekumpul's middle class community.

\section{Commodification}

The growing interest of the new middle class in the current wave of market-friendly Islam has spread to a large and diverse segment of

${ }^{29}$ For a further account on ethno-religious conflicts in Sampit and other provincial towns during the late 1990s, see Gerry van Klinken, Communal Violence and Democratization in Indonesia. Small Town Wars (London and New York: Routledge, 2009).

${ }^{30}$ Interview with Ismail Morsade, Martapura, 20 February 2008.

${ }^{31}$ Interview with Nafsiah, religious figure who resides in Sekumpul Neighborhood, 11 February 2008; and Dede Hidayatullah, civil servant who also resides in Sekumpul, 22 February 2008. 
Indonesian Muslims, leading to the expansion of market opportunities for commercial products related to these activities. It is logical that while demands have increased for the latest innovative models of religious expression, Indonesian fashion designers, the garment industry and other business players gear up to launch new products. Again, the middle class plays a pivotal role, not only as loyal consumers of the products, but also as commercial agents providing affordable 'Islamic' products that follow (or even set) the latest fashion trends. As commercial agents, they distribute the products widely to reach remote areas in the countryside. Indeed, their roles as commercial agents in the process of religious commodification cannot be ignored. Religious commodification should not be confused with commercialization. It is not a phenomenon that exists solely to make money. Religious commodification entails the ideologization of commodities and the commoditization of religion, as it is as much about selling ideology as it is about selling products. ${ }^{32}$ Religious commodification has in fact very much to do with the way religion, in this case Islam, is packaged and offered to a broader audience, and how this has produced a framework for the moral order of society through the objectification and systematization of Islamic values and practices as a normative model.

Middle class entrepreneurs are at the forefront in transforming Islam into a symbolic commodity relevant to class-based demands for lifestyle, modesty and enjoyment, and therefore no longer simply a set of rituals, beliefs and doctrines. Sociological debate of this phenomenon conceptualises consumption in the modern age as one of the most crucial, defining class experiences, and an expression of identity and representation of the self. This is related to the notion of embodiment which suggests that "all the fundamental processes of conception, perception, evaluation and judgement are connected to the fact that human beings are embodied social agents." 33 Since religion has emerged as a symbol of elitism associated with the road to success, statements of one's personal identity can involve the use and consumption of religious

${ }^{32}$ Ronald Lukens-Bull, "Commodification of Religion and the 'Religification' of Commodities," in Pattana Kitiarsa (ed.), Religious Commodifications in Asia: Marketing Goods (London and New York: Routledge, 2008), pp. 220-234.

${ }_{33}$ Bryan S. Turner, "Preface," in Parci Falk, The Consuming Body (London: Sage Publications, 1994). 
symbols, as can be seen in the role of Islam within the Indonesian public sphere. In the hands of middle class entrepreneurs, the symbols of faith have thus become commodified as markers of social status. Miller suggested that commodifying religion has reduced religious beliefs, symbols, and values into free-floating signifiers to be consumed like anything else. ${ }^{34}$ As such, it takes them from their original contexts and throws them into a cultural marketplace where they can be superficially embraced without being actually put into practice.

The heart of the commodification process is found in places such as the sprawling Tanah Abang market in metropolitan Jakarta, where countless tightly packed stalls are festooned with products from small to middle scale industries. These industries also operate in provincial towns such as Tasikmalaya, Pekalongan and Solo. They not only meet market demands, but also set market trends nationally. This reciprocal relationship is driven by business intuition and acumen rather than religious motivation. This 'Islamic industry' thrives in parallel with the emergence of upwardly mobile consumers, who seek models of behavior appropriate to their new elevated status. But the end result is determined by those on the economic margins who "show a fascination with the cultural codes associated with the wealth and power of the new elites." ${ }^{\prime \prime}$

The sprouting of Islamic symbols in Indonesian provincial towns is almost identical to the success of the middle class in expanding business. In Kebumen, many people have been able to open stores along Sutoyo, Kolopaking and Kusuma streets, selling mobile phones, electronic gadgets, ready-made garments and much more. Market competition has been enlivened by the entry of new players, kyais or young figures who are closely affiliated with the biggest Islamic organizations in Kebumen, NU and Muhammadiyah. One of them, Wahib Machfudz, owns a number of stores under the label Al-Huda, the same name as his pesantren, selling books, clothing and electronic accessories, as well as several telephone shops. Another successful businessman, Cholidi Ibhar, is a former local parliamentarian from the Partai Kebangkitan Bangsa/PKB (Party of Nation Awakening) in Kebumen. He specializes

${ }^{34}$ Vincent J. Miller, Consuming Religion: Christian Faith and Practice in a Consumer Culture (New York: Continuum, 2004).

${ }^{35}$ Ken Young, "Consumption, Social Differentiation and Self-Definition of the New Rich,” p. 57. 
in selling Muslim fashion under his own label Amanah, in competition with similar shops such as Tadzkiya, Zahra, Mangga Dua, Tiara 27, and Asri. As well as these retailers, several young NU and Muhammadiyah activists such as Slamet Faisol and Muhammad Dahsyad have become wholesale clothing supply agents to small retail stores throughout Kebumen. Other prominent business players with santri backgrounds have arisen in Kebumen to creatively broaden the market coverage of local commodities. Among them are Yahya Mustafa, Ibnu Ashari, Mastur Soba'i A ziz, Ayub, and Slamet Faisol. Yahya Mustafa has become the most prominent of them all by expanding basket weaving craftwork for export, and was given the (bank) Danamon Award for his hard work. Another success story is that of Ibnu Ashari, now the owner of Sriti plastic cutting factory located in Kelurahan Watubarut, Kebumen. This entrepreneur has an NU background, and was once active in Ansor and Garda Bangsa Kebumen (2002-2007). He opened his own factory after working for ten years in the Naga Semut plastic factory, owned by the Chinese entrepreneur Tan Han Jian. ${ }^{36}$

The establishment of the Sentral Ekonomi Muslim (SEM/Centre of Muslim Economy), in Sutoyo Street near Tumenggungan traditional market, is emblematic of the emerging middle class enterpreneurs in Kebumen, which has witnessed a marked shift in class formation. In 2004, SEM was built on land donated to the Darussalam Mosque, situated in Kebumen sub-district. In cooperation with an investor, 68 kiosks were built but unfortunately not more than 10 kiosks in the front row were able to stay in business. The remaining kiosks were closed, or never even opened. A lot of effort has gone into invigorating this market, mostly to settle the debts of the wholesalers who invested Rp 1.2 billion for construction of the kiosks. ${ }^{37}$ Initially SEM was be a convenient shopping centre where the emerging middle class in Kebumen could spend their money and meet their growing need for 'Islamic' clothing and accessories, thus strengthening their class distinction. However since it was not modelled after luxurious shopping malls in Yogyakarta and other cities in Central Java, SEM never evolved into an important shopping centre

\footnotetext{
${ }^{36}$ Interview with Ibnu Ashari, 14 January 2008.

${ }^{37}$ Interview with Nurhadi, member of Nadzir Darussalam Mosque, 17 March
} 2008. 
bringing pride to Kebumen society. This fact indicates that marketing Islamic commodities by itself is not enough - they need to be marketed in the modern way, and not through kiosks in a traditional market.

In the middle of SEM's failure, the Jadi Baru Mall (JB) was built, despite opposition from the traditional traders and Chinese businessmen of Kebumen. JB belongs to a supermarket network centred in the Kroya, Cilacap. It was built by an entrepreneur from Cilacap, Mahasin, the besan (relationship between parents whose children are married to each other) of an influential cleric, Gus Anam, from Leler Banyumas. The construction of JB was supported by local Kebumen public figures. One of them, Yazid Machfudz, is the brother of Wahib Machfudz, the chairman of the consultative council of the NU branch of Kebumen and a businessman. There has long been a tight bond between Mahasin and Yazid. Yazid was convinced that the development of JB would bring prosperity to the Muslim community, because the owner is a member of NU and the mall would improve Kebumen's economy by attracting new people and new life to a part of town that was currently deserted. ${ }^{38} \mathrm{JB}$ would have a special section for Muslim Women's Wear, complete with all the accessories and gadgets needed by women who wanted to appear 'Islamic' and yet modern.

The middle class' ability to expand their business network by selling 'Islamic' products is also evident in Martapura. Realizing Sekumpul's market value, Guru Zaini launched Al-Zahra productions, a brand name for the numerous merchandise, accessories and gadgets associated with the Sekumpul. The core products of Al-Zahra are Muslim fashion, prayer/ritual attire and accessories, with its production lines located in Tasikmalaya and Surabaya. Al-Zahra later expanded its production line with the opening of the Ar-Ruhama bookstore and Ar-Raudhah publications. Both of these businesses were put under independent management, and Guru Zaini focussed on Al-Zahra. Besides the ritual merchandise shops and Muslim women's fashions under the umbrella of Gallery Al-Zahra, Al Zahra now has business lines such as Al-Zahra Fast Food, imitating the model of California Fried Chicken, AZ Bakery and Al-Zahra Supermarket. Al-Zahra also produces its own mineral water, branded simply as 'Sekumpul'.

\footnotetext{
${ }^{38}$ Interview with Yazid Machfudz, 7 November 2007.
} 
Al-Zahra claims the source of its business inspiration is Aa Gym's Management Qalbu Corporation, but with Guru Zaini as a marketing figure to target certain market segments, particularly in provincial towns of South Kalimantan. Al-Zahra's major selling point was the fact that it was owned by Sekumpul, and it grew dramatically. Even after the death of Guru Zaini in 2005, Al-Zahra still stands strong. Its consumers are the thousands of visitors coming to Sekumpul every day. Although the popularity of Sekumpul as a centre of ritual seems to have faded slightly, Martapura still remains a religious and social magnet for provincial towns of South Kalimantan and Sekumpul business enterprises continue to expand. The expansion of Sekumpul businesses has been backed by many succesful enterpreneurs, including Sarkani, Norhid, Assegaf, and Morsade. These enterprenuers have developed various 'Islamic' type business enterprises of their own, inspired by the Sekumpul. ${ }^{39}$ For instance, a real estate company owned by Morsade has developed exclusive 'Islamic' residences in Banjarbaru, near Martapura, named the Ismor housing complex after the abbreviation of his name. ${ }^{40}$

What we have seen here is the prominent role of the new middle class as an agency to facilitate the process of religious commodification. Agency here specifically refers to the capacity of Muslims to realize their own interests against the dominant ideology that makes it difficult to reconcile piety and other forms of public religious expression with modernity. ${ }^{41}$ An active engagement in the construction of religious debate and discourse in the public space primarily characterizes this particular type of agency, through which a new form of interpretation and meaning is offered for religious expressions and identities. A criticism of the religious establishment is inherent in its efforts to counter hegemonic discourse and passivity that characterizes religious traditionalism. In contrast to Mahmood's understanding of agency in the case of the mosque's woman movement in Egypt, which was centred on

${ }^{39}$ Interview with Ridwan, Former Director Al Zahra, 17 February 2008, and Rizki Wijayakusuma, Ahmad Diauddin and Suriani, admin staff of Al-Zahra, 19 February 2008.

${ }^{40}$ Interview with Ismail Morsade, Martapura, 20 January 2008.

${ }^{41}$ On the concept of agency, see Anthony Giddens, The Constitution of Society. Outline of the Theory of Structuration (Cambridge: Polity, 1984); see also, his Social Theory and Modern Sociology (Cambridge: Polity, 1987). 
individual intentions to engage in self-transformation through passivity and feminine docility and not solely through the lens of subversion, agency in this context involves the process of social transformation and strategic choices. ${ }^{42}$ Instead of giving up religiosity, considered as a source of backwardness, it liberalizes religion from its traditionally subservient, passive and docile posture by turning it into a source of moral legitimacy and distinction to represent a modern form of life.

The fact that the growing trend for women in Indonesian provincial towns to wear headscarves is tied to the larger process of social change sheds some light on the importance of agency in the process of negotiation between tradition and modernity. As Brenner observed, the practice of veiling among women in Java represents both a new historical consciousness and a transformation of self that challenges local tradition as well as Western models of modernity. Veiling is thus perceived as an active process to produce a vision of a society that is distancing itself from the past as it embarks upon a new modernity. ${ }^{43}$ Indeed, veiling allows middle-class women in Java to live away from home and move into predominantly male social, political and economic spaces with a heightened commitment to the profession of Islam. ${ }^{44}$ In fact, the wearing of the headscarf helped Rustriningsih, the then Kebumen district head, to secure her position as the first woman to hold the highest political position in Kebumen. As well as her pioneering efforts to improve transparency and good governance in Kebumen, Rustriningsih's politics of veiling played a significant role in her success in winning support from the majority of Kebumen society. No less significant, Rustriningsih's veiled performance became a style reference and established a dress code

${ }^{42}$ Saba Mahmood, Politics of Piety: The Islamic Revival and the Feminist Subjects (Princeton and Oxford: Princeton University Press, 2005). For critiques of her theory, see, for instance, Farzana Haniffa, "Piety as Politics amongst Muslim Women in Contemporary Sri Lanka", Modern Asian Studies 42, $2 / 3$ (2008): 347-75; Rubina Jasani, "Violence, Reconstruction and Islamic Reform—Stories from the Muslim 'Ghetto", Modern Asian Studies 42, 2/3 (2008), pp. 431-56.

${ }^{43}$ Suzanne Brenner, "Reconstructing Self and Society: Javanese Muslim Women and 'the Veil,' American Ethnologist 23, 4 (1996), pp. 673-697.

${ }^{44}$ Nancy J. Smith-Hefner, "Javanese Women and the Veil in Post-Soeharto Indonesia," Journal of Asian Studies 66, 2 (2007): 389-420; see also Deny Hamdani, "The Quest for Indonesian Islam: Contestation and Consensus Concerning Veiling," PhD Dissertation, Australian National University: 2007. 
for many politicians, religious leaders and other members of the middle class in Kebumen. ${ }^{45}$ Once Islamic attire was adopted by Kebumen's elite and middle class, the koko shirt and the trendy jilbab became popular throughout Kebumen.

\section{E. Islam in Local Politics}

Because of Islam's complex relationship with tradition, locality, modernity, as well as globalization, it is hard to determine whether Indonesia has actually reached the brink of a post-Islamist turning point. Such a turning point would be signaled by a shift in Islamic activism from collective activism that is revolutionary in character, towards an individual activism which accepts the imperatives of modern life. If the first is shaped by ideologies, what Bayat defines as 'post-Islamism' distances itself from political nuances and collective militancy, whilst still ensuring harmonization and parallelism between Islam and modernity. ${ }^{46}$ No doubt, the reality of an electoral democratic system that guarantees much broader public participation in politics, however shallow this participation may be, serves as a catalyst for the burgeoning of public Islam. It is a concept that refers to the appearance of an "Islamic" public sphere which enables a large segment of diverse Muslims to make their voices heard in civic debate and public life, thus facilitating a modern and distinctively open sense of political and religious identity. ${ }^{47}$ Being embedded in a combination of both public display and public discourse, public Islam constitutes an ordering and rationalizing that is expressed in Islamic terms but coheres in a unified normative principle. In so doing, it plays a significant role in channelling social change, securing social order and promoting grass-roots democratisation in Muslim societies. ${ }^{48}$

${ }^{45}$ Interview with Dawamuddin Masdar, an NU leader in Kebumen, Kebumen, 9 January 2008.

${ }^{46}$ Asef Bayat, Making Islam Democratic, Social Movements and the Post-Islamist Turn (Stanford, CA: Stanford University Press, 2007), pp. 10-11.

${ }^{47}$ Armando Salvatore and Dale Eickelman, "Public Islam and the Common Good," in Armando Salvatore and Dale F. Eickleman (eds.), Public Islam and the Common Good (Leiden, Boston: Brill, 2004), pp. xi-xxv.

${ }^{48}$ Armando Salvatore, "The Genesis and Evolution of 'Islamic Publicness' under Global Constraints," Journal of Arabic, Islamic and Middle Eastern Studies 3, 1 (1996), pp. 51-70. 
In other words, public Islam is a process that sheds some light on the significance of religion in the dynamics of public life of contemporary Muslim societies.

The increase in the public visibility of religion in today's politics is actually not unique to Muslims. As Casanova has argued, religions in the globalizing era have entered the public sphere and the arena of political contestation to participate in the very struggles to define and set the modern boundaries between the private and public sphere, between system and life-world, between family, civil society and state, between nations, states, civilizations and the world system. ${ }^{49}$ It is the era when the wall of secularization separating the secular and religious realms- which entails the privatization of religion-breaks down and faces a serious challenge ${ }^{50}$ For Casanova, the appearance of religions in the public spaces of the globalizing era facilitates a new institutionalization of processes of practical rationalization and thus the fading boundaries between the private and the public. By entering the sphere of public communication, religions are induced to a 'reflexive rationalization' of the lifeworld, which entails a reconfiguration of the private-public dichotomy and of its boundaries. ${ }^{51}$

The burgeoning of public Islam is related to the rapid current of modernization and globalization and the nation's on-going democratic consolidation. Following the shift towards a consumerist society as a result of globalization, religion is experiencing commodification as piety becomes part of the drama of self identity and representation, and the statement of the self in the public space. As an alternative to religious radicalism, it offers Muslims a way to actualize religious beliefs and values while still following the path of modernity and globalization, without plunging into violence and joining a cycle of militancy. Democratic values, which form the foundations of practical Islam and the politics of contemporary Muslim society, suggest that being a democratic Muslim is no longer an oxymoron. ${ }^{52}$

${ }^{49}$ Jose Casanova, Public Religions in the Modern World (Chicago: University of Chicago Press, 1994), p. 6.

${ }^{50}$ Ibid., pp.11-19.

${ }^{51}$ Ibid., pp. 228-229.

${ }^{52}$ Seyyed Vali Reza Nasr, “The Rise of 'Muslim Democracy'.” Journal of Democracy 16, 2 (2005), pp. 13-27. 
The complex relationship between Islam and democracy is made manifest when its symbols have assumed a greater significance in the dynamics of local politics. The importance of religious symbols in local politics lies in their ability to legitimize elites in power and their collaborators in their attempt to respond to the challenges of the opposition, including militant Islamists. This has led those in power to appropriate religious symbols and Islamist idioms, for the instrumental purposes of claiming the mantle of Islam and delegitimizing the Islamist opposition, while simultaneously producing a greater harmony of statesociety relations. ${ }^{53}$ By mobilizing religious symbols, new political elites from the santri background, who have links to prominent ulama and their pesantren, were involved in negotiations for boundaries in terms of political power, economic arrangements, as well as the redefinition of group identities. Interestingly, when a multiplicity of actors have the opportunity to interpret symbols differently, in accordance with their own interests, Islamist attempts to dominate the interpretation of those symbols, and thereby transform the Indonesian secular democratic system into an Islamic state, have increasingly lost ground. In this process religious symbols have irrefutably been distanced from their religious moorings and narrow, Islamist understandings, in favor of pragmatic political purposes.

This phenomenon often looks like a paradox. Democracy requires a liberation of public spaces from the domination of narrow religious, ethnic and primal sentiments. If these were to resurface in the political arena they could affect the very process of democratic consolidation. But on the other hand, religious symbols may play a pivotal role in political mobilization. They can legitimize the ruling elite and provide the means for them to counter and deligitimize their opposition, including militant Islamists. The situation is rendered more complex by the fact that democracy cannot deny interest groups access to those same symbols, which can then be used to pursue narrow, group-specific interests. In exchange for support in local elections, for instance, regional political leaders may well exploit religious symbols and align themselves with the

${ }^{53}$ Seyyed Vali Reza Nasr, Islamic Leviathan. Islam and the Making of State Power (Oxford: Oxford University Press, 2001), p. 106. For the context of Malaysia, see Joseph Chinyong Liow, Piety and Politics. Islamism in Contemporary Malaysia (Oxford: Oxford University Press, 2009), pp. 11-12. 
religious majority in decision-making. By ignoring the basic principles of democracy, regional autonomy can become more corrupt and exploitative than the highly centralized government of the New Order, and thus become a stumbling block to achieving the public good.

When Indonesia adopted regional autonomy and Jakarta decentralized many, but not all, of its political and financial powers, the matrix of power relations became more complex. The nexus between the interests of regional elites, resource competition and ethnic-cum-religious divisions seems to have driven the dynamics of local politics in Indonesia's many different regions. All these phenomena are in fact symptoms of the weakening of the central state, which interestingly does not automatically result in more democratization, good governance and the strengthening of civil society. As Nordholt and van Klinken have shown, despite the process of decentralization, political and economic development at the regional level seemed doomed. Its process is challenged by bureaucratic sabotage, corrupt power politics, short term opportunism, and the absence of a widely shared vision of the future. Moreover, the relative weakness of civil society has accompanied the emergence of new forms of authoritarian rule and the continuity of the existing patrimonial patterns. Particular bureacratic and political elites mobilized ethnic-cumreligious sentiments to achieve their goals. ${ }^{54}$ It should be noted, however, that approaching the issue from a linear model of democratization, these authors are apparently more tempted to underscore the paradoxes of decentralization in post-Suharto Indonesia at the expense of the more nuanced dynamics of the process itself.

The case of Kebumen is again worth noting in this context. Rustriningsih represents the ability of the middle class to make use of religious symbols, ideologies and solidarities and give them multiple interpretations to legitimize their own claims at a time when democratic idioms have increasingly gained ground in Indonesian provincial towns. As a successful, thirty-five year old woman wearing a colourful headscarf and a fashionable two-piece suit, with a long skirt, for her public performances, Rustriningsih's new image spoke loudly of the

${ }^{54}$ Henk Schulte Nordholt and Gerry van Klinken, "Introduction", in Henk Schulte Nordholt and Gerry van Klinken (ed.), Renegotiating Boundaries Local Politics in Post-Subarto Indonesia (Leiden: KITLV Press, 2007), pp. 1-29. 
compatibility of Islam with modernity. She responded to the harsh critiques of her Islamist rivals, especially those in the Front Thariqatul Jihad (FTJ), who questioned her abangan background as being unfriendly to Islam. She also challenged the Islamist and conservative Muslim rejection of women in public spaces and their right to political positions in the male dominated region in Kebumen. The wearing of a headscarf certainly did not indicate Rustriningsih's agreement with the Islamist agenda, by which public moral order and personal behavior should be governed according to the precepts of militant Islamist ideology. It can be seen instead as evidence of the gender struggle to reconstruct the segregating social norms that subordinate women. Thus Rustriningsih was exercising public agency to deconstruct social taboos, and to reconfigure the collective social imagination to accept that being a good Muslim woman does not require withdrawal from public spaces and social relations. Becoming a good Muslim woman may instead mean having the courage to stand tall in public, and to lead others through change for the better. Once Rustriningsih started wearing a headscarf she no longer hesitated to talk about good governance, democracy, and poverty reduction.

The importance of religious symbols in the dynamics of local politics following Suharto's demise appears also to be linked to incremental efforts by district and municipal level governments to redefine their regional identities. Suharto's highly centralized New Order government discouraged real regional identity, and maintained close control over the resources of the nation's various regions, as well as their political and economic development. In fact, "the New Order government was ethnocentrically controlled by the Javanese, and therefore, all forms of Javanese culture were supported and underpinned the regime's cultural policies and imaginings." ${ }^{55}$ This 'Javanization' of Indonesia was increasingly seen as exerting a stranglehold on the lives of the Indonesian people. Especially outside Java, there were many who felt that they had never really enjoyed the fruits of 30 years of New Order development, but instead bore the brunt of corruption, collusion and nepotism from

${ }^{55}$ Kendra Clegg, "The Politics of Redefining Ethnic Identity in Indonesia: Smothering the Fires in Lombok with Democracy," in Nicholas Tarling and Edmund Terence Gomez (eds.), The State, Development and Identity in Multi-Ethnic Societies. Ethnicity, Equity and the Nation (London and New York: Routledge, 2008), p. 177. 
the centre. ${ }^{56}$ Law No. 22/1999 on local autonomy was therefore welcomed with enthusiasm. This law drastically limited the authority of the central government, and devolved considerable authority to district governments, thereby strengthening the position of the local government at the district and municipal levels. ${ }^{57}$ Despite the fact that regional, religious, and ethnic identity politics assumed much greater importance, ${ }^{58}$ decentralization is widely recognized as a major and necessary step towards nurturing a flourishing democracy by giving space for people to participate in local political processes. ${ }^{59}$

Local elite political groups adopted a range of strategies to redefine and strengthen regional identity as a means of increasing their electoral support. As well as reinventing historical legacies and memories, they mobilized religious symbols and other forms of cultural capital, including support from the 'ulama. As is evident in the case of Martapura, Rudy Ariffin sought to secure sympathy and support from the 'ulama shortly after he was elected as the district head in 2000. The most charismatic ulama in Martapura, Guru Zaini, did not initially support Ariffin and his running partner Mawardi Abbas. Guru Zaini’s support was enormously important. As the murshid (Sufi adept) of the Sammaniyah Sufi Order, he had wide influence among Muslims throughout Kalimantan. Ariffin made all-out efforts to persuade Guru Zaini. His relentless efforts were blessed with a stroke of good luck when he was made responsible for arranging President Abdurrahman Wahid's visit to Sekumpul in 2001, thus providing him a golden opportunity to make closer contact with

${ }^{56}$ Priyambudi Sulistiyanto and Maribeth Erb, "Introduction: Entangled Politics in post-Suharto Indonesia," in Maribeth Erb, Priyambudi Sulistiyanto and Carole Faucher (eds.), Religionalism in Post-Subarto Indonesia (London and New York: Routledge, 2005), pp. 1-17.

${ }^{57}$ Pratikno, "Local Autonomy and Democracy in Indonesia, 1999-2001," in Maribeth Erb, Priyambudi Sulistiyanto and Carole Faucher (eds.), Religionalism in PostSubarto Indonesia (London and New York: Routledge, 2005), pp. 21-35.

${ }^{58}$ Henk Schulte Nordholt and van Klinken, "Introduction," in Renegotiating Boundaries Local Politics in Post-Subarto Indonesia, pp. 1-29.

${ }^{59}$ Priyambudi Sulistiyanto and Maribeth Erb, "Indonesian and the Quest for Democracy," in Maribeth Erb and Priyambudi Sulistiyanto (eds.), Deepening Democracy in Indonesia? Direct Elections for Local Leaders (Pilkada) (Singapore: ISEAS, 2009), pp. 1-37. 


\section{Guru Zaini. ${ }^{60}$}

Ariffin's drive to reinforce the image of Martapura as the front porch of Mecca underpinned his proposal to enact shari' $a$ by-laws. For the political elite of Martapura, the complete congruence of Islam and Banjarese culture is unrefutable. Referring to the thesis proposed by local anthropologist Alfani Daud, the main concept underlying the by-laws is that "Islam is Banjar and Banjar is Islam." In his opinion, however, the pressures of rapid modernization and globalization and Jakarta-centric development had resulted in the fading influence of Islam as the most important source of reference among the Banjarese people. As a consequence, social problems and moral diseases such as gambling, adultery, drug addiction and other forms of 'vice' had spread widely, especially among Martapura's younger generation. He argued that this problem is of concern not only to the government, but also 'ulama and ordinary citizens, and thus urged the local government to enact the by-laws. ${ }^{61}$

Matters assumed a greater urgency when a paramilitary organization, Garusikat (the Movement of Muslims to Remove Social Ills), was established with support from such conservative 'ulama as Anang Jazouly Seman, and actively took to the streets calling for the shari' $a{ }^{62}$ Its organizational structure and operational concept were proposed by Badru 'Ain Sanusi al-Afif, a former NGO activist who was also active in advocacy programs. A daring religious teacher, Suhaimi, was appointed as the group's commander, backed-up by former influential thugs, including Hasan Sinso. The police saw Garusikat as a challenge to their authority, and eventually responded by sponsoring the establishment of a similar organization named Dalas Hangit under the leadership of Utuh Hirang, another former thug. There was considerable tension between the two groups, resulting in actual conflict. They only reached peaceful agreement

${ }^{60}$ Interview with Anang Armawan, former bupati candidate, Martapura, 10 February 2008, and with Fauzan Saleh, the Chairman of the Executive Council of NU branch in Martapura, 13 February 2008.

${ }^{61}$ Interview with Mashuri, former chief of the social office and now of the economic office at the Banjar regency, 16 February 2008.

${ }^{62}$ Interview with Mawardi Abbas, Martapura, 16 February 2008. 
after mediation by Guru Zaini. ${ }^{63}$

The shari'a by-laws allowed Ariffin to systematically locate Islam at the epicentre of the town's bureaucratic orbit. What has been called the bureaucratization of Islam has taken place through a conscious decision to Islamize the government and adopt policies to achieve this end. ${ }^{64}$ When Martapura started promulgating shari' $a$ by-laws, every part of the bureaucratic machinery began competing to demonstrate its superior commitment to Islam. All manner of bureaucratic cogs in the government wheel became active in organizing religious lectures and other religious activities. To strengthen his policy of Islamizing the bureaucracy, Ariffin then issued a circular letter recommending that all woman civil servants in the Banjar administration and related institutions throughout the region wear headscarves. Although this only had the strength of a recommendation, the letter made no allowance for women working in government offices who happened to be Christian, Hindu or Buddhist. They should all wear headscarves. They were made to feel uncomfortable if they did not wear headscarves in their interactions with superiors or other civil servants. ${ }^{65}$

When Khairul Saleh replaced Ariffin, the policy of redefining regional identity and Islamizing the bureaucracy by insisting on the need for shari' $a$ by-laws continued unabated. He ratified a proposal by the local legislators for a regulation requiring the insertion of Jawi (Malay-Arabic) script on office nameplates in all Martapura's government offices. He claimed that this policy was part of his drive to disseminate the Islamic ethos throughout all government units and offices in the region, an ethos that packages the internalization of piety, honesty, and good performance. His rationale was that the Jawi script uses the Arabic alphabet to write the Malay language, and that this script was once common in the Banjar sultanate and other Malay Islamic kingdoms. Its significance for Saleh was that the Jawi script is identical to the alphabet of the Qur'an, which

${ }^{63}$ Interview with Rizki Wijayakusuma, former NGO activist, Martapura, 19 February 2008.

${ }^{64}$ On the notion of the bureaucratization of Islam and how this policy has begun to work out especially in the context of Malaysia under Mahathir's government, see Liow, Piety and Politics, pp. 46-48.

${ }^{65}$ Interview with Masnur Manurung, a Christian woman civil servant in the Banjar regional administration office, 12 February 2008. 
is the ultimate guide to Muslim behaviour in both public and private life. ${ }^{66}$ Saleh is known as a qari (Qur'anic reciter in rhythmic tones), and he intersperses his public speeches or briefings with fluent quotations from the Qur'an and the Prophetic Traditions (hadith). Reinforcing Islam's public voice in Martapura's bureacratic sphere, Salawat (salutation to the Prophet Muhammad) and Qur'anic verses, rather than patriotic and national songs, are often used as interludes at important government events. Every morning civil servants in the Banjar regency listen to a short sermon, piped into their offices, on the importance of such virtues as piety, transparency, honesty, and the ethos of meritocracy for the success of regional development - laced with Qur'anic quotations.

\section{F. Conclusion}

The mushrooming of Islamic symbols in the public spaces of Indonesian provincial towns after Suharto occurs alongside significant shifts in social, economic and political fields, due to the mounting impact of Islamization, social mobility, economic growth, and democratization occurring among town people. It is as if we see a parallel move between Islamization, modernization, globalization as well as democratization, although key concepts associated with these trends are appropriated along with those rooted in tradition and local culture to inform the whole dynamics of Indonesian provincial towns today. This is the main feature of the provincial towns that attempt to negotiate the global and the local smoothly. The key player in this process is the new middle class, who look to Islam for inspiration both to claim distinction and social status and to legitimize their consumptive lifestyle. They are newly pious who act as active negotiators between the global and the local as well as the cosmopolitan centre and the hinterland. They also play a pivotal role as an agency that liberalizes religion from its traditionally subservient, passive and docile posture by turning it into a source of moral legitimacy and distinction to represent a modern form of life.

The growing interest of the middle class in a market-friendly Islam-based lifestyle has spread to a large and diverse segment of Indonesian Muslims, including those on the economic margins who show

${ }^{66}$ Interview with Khairul Saleh, the Regent of Banjar, Martapura, 21 February 2008. 
a fascination with the cultural codes associated with the wealth and power of the new elites. The expansion of market demands and opportunities for commercial products related to Islam facilitates the phenomenon of religious commodification, which is very much related to the way religion is packaged and offered to a broader audience. The role of the middle class is crucial as both loyal consumers as well as commercial agents, widely distributing the latest trends in 'Tslamic' products into remote areas in the contryside. They are at the forefront in transforming Islam into a symbolic commodity which is not totally uprooted from tradition and culture, but relevant to upwardly mobile consumer demands for lifestyle, modesty and enjoyment. The end result of this process is determined by the way in which Indonesian provincial towns are willing to distance themselves from the past as they embark upon a new modernity.

Given its intimate relationship with locality, tradition, modernity as well as globalization, Islam has increasingly assumed a greater importance for local politics. Political elites have used Islamic symbols for the instrumental purpose of extending their political legitimacy and mobilizing constituency support, in a political environment of open competition and increased public participation in decision making. In this process, religious symbols have irrefutably been distanced from their religious moorings and narrow, Islamist understandings, in favor of pragmatic political purposes. Thus the adoption of the headscarf (jilbab) by Kebumen's district head, Rustriningsih, in her official performance remains an empty gesture, or even a middle-class elitist symbol, unless the jilbab has become an authentic expression of her lifestyle. Seen from a similar perspective, the application of shari'a bylaws in Martapura is best understood not as evidence of the growing influence of Islam in politics, but rather as the maneuverings of the town's political elites in their efforts to secure their own interests. The bylaws nonetheless allowed the elites to systematically attempt to locate Islam at the heart of the town's bureaucratic orbit. The growing realpolitik relevance of Islam at the local context has facilitated its emergence as a source of legitimacy for Indonesian provincial towns' struggle for regional development and modernization, while maintaining their connection with tradition and local culture. 


\section{BIBLIOGRAPHY}

Abaza, Mona, "Markets of Faith: Jakarta Da'wa and Islamic Gentrification," Archipel 67, 2004.

Alexander, Jennifer, Trade, Traders and Trading in Rural Java, Singapore: Oxford University Press. 1987.

Alfisyah, "Agama dan Tingkah Laku Ekonomi Urang Banjar, Studi atas

Pedagang Sekumpul Martapura Kalimantan Selatan," Unpublished MA Thesis, Yogyakarta: Universitas Gadjah Mada, 2005.

Alhakim, Zain, “The Sekumpul of 'Diamond' Master Teacher," in Asrori

S Karni, ed., A Celebration of Democracy A Journalistic Portrayal of Indonesia's 2004 Direct Elections Amongst Moderate and Hardline Muslims, Jakarta: Era Media Informasi, The Wahid Institute and the Asia Foundation, 2006.

Anwar, A. Syafi'i, Pemikiran dan Aksi Islam Indonesia. Sebuab Kajian Politik tentang Cendikiawan Muslim Orde Baru, Jakarta: Paramadina, 1995.

Ariffin, Rudy, "Martapura Bumi Serambi Mekkah,” in Nurhudianto (ed.), Martapura Bumi Serambi Mekkah, Secunting Pemikiran Rudy Ariffin, Martapura: Pemkab Banjar, 2004.

Bayat, Asef, Making Islam Democratic, Social Movements and the Post-Islamist Turn, Stanford, CA: Stanford University Press, 2007.

Bourdieu, P., Distinction: A Social Critique of the Judgement of Taste, London: Routledge and Kegan Paul, 1984.

Brenner, Suzanne, "Reconstructing Self and Society: Javanese Muslim Women and 'the Veil', American Ethnologist 23, 4, 1996.

Budiman, Arif, "From Lower to Middle Class: Political Activities Before and After 1988," in David Bourchier and John Legge (eds.), Democracy in Indonesia 1950s and 1990s, Sidney: Centre of Southeast Asian Studies at Monash University, 1994.

Casanova, Jose, Public Religions in the Modern World, Chicago: University of Chicago Press, 1994.

Clegg, Kendra, "The Politics of Redefining Ethnic Identity in Indonesia: Smothering the Fires in Lombok with Democracy," in Nicholas Tarling and Edmund Terence Gomez (eds.), The State, Development 
and Identity in Multi-Ethnic Societies. Ethnicity, Equity and the Nation, London and New York: Routledge, 2008.

Dick, H.W., "Further Reflections on the Middle Class," in Richard Tanter and Kenneth Young (eds.), The Politics of Middle Class Indonesia, Clayton, Australia: Centre for Southeast Asian Studies, 1990.

----, "The Rise of a Middle Class and the Changing Concept of Equity in Indoesia--An Interpretation”, Indonesia 39, 1985.

Featherstone, M., "Lifestyle and Consumer Culture," in E. Meijer, ed., Everyday Life: Leisure and Culture, Tilburg: Department of Leisure Studies University of Tilburg, 1987.

Fischer, Johan, Proper Islamic Consumption, Shopping Among the Malays in Modern Malaysia, Copenhagen: NIAS Press, 2008.

Giddens, Anthony, Social Theory and Modern Sociology, Cambridge: Polity, 1987.

----, The Constitution of Society. Outline of the Theory of Structuration, Cambridge: Polity, 1984.

Göle, Nilufer, "Islamic Visibilities and Public Sphere," in Nilufer Göle dan Ludwig Ammann (eds.), Islam in Public Turkey, Iran, and Europe, Istanbul: Istanbul Bilgi University Press, 2006.

Guinness, Patrick, "Local Society and Culture," in Hal Hill (ed.), Indonesia's New Order: The Dynamics of Socio-economic Transformation, Honolulu: University of Hawaii Press, 1994.

Hamdani, Deny, "The Quest for Indonesian Islam: Contestation and Consensus Concerning Veiling," PhD Dissertation, Australian National University: 2007.

Haniffa, Farzana, "Piety as Politics amongst Muslim Women in Contemporary Sri Lanka”, Modern Asian Studies 42, 2/3, 2008.

Hasbullah, Moeflich, "Cultural Presentation of the Muslim Middle Class in Contemporary Indonesia," Studia Islamika 7, 2, 2000.

Hefner, Robert W., Civil Islam, Muslim and Democratization in Indonesia, Princeton: Princeton University Press, 2000.

Heryanto, Ariel, "Indonesian Middle-Class Oppositon in the 1990s," in Garry Rodan (ed.), Political Oppositions in Industrializing Asia, London and New York: Routledge, 1996. 
----, “The Years of Living Luxuriously. Identity Politics of Indonesia's New Rich," in Michael Pinches (ed.), Culture and Privilege in Capitalist Asia, London and New York: Routledge, 1999.

Jasani, Rubina, "Violence, Reconstruction and Islamic Reform-Stories from the Muslim 'Ghetto"', Modern Asian Studies 42, 2/3, 2008.

Klinken, Gerry van, Communal Violence and Democratization in Indonesia. Small Town Wars, London and New York: Routledge, 2009.

Kuntowijoyo, "Serat Cebolek dan Mitos Pembangkangan Islam: Melacak Asal-Usul Ketegangan antara Islam dan Birokrasi," Ulumul Qur'an 5, 1 (1990) 63-72.

Lev, Daniel S., "Intermediate Classes and Change in Indonesia: Some Initial Reflections," in Richard Tanter and Kenneth Young (eds.), The Politics of Middle Class Indonesia, Clayton, Australia: Centre for Southeast Asian Studies, 1990.

Liddle, R. William, "The Middle Class and New Order Legitimacy: A Response to Dan Lev," in Richard Tanter and Kenneth Young (eds.), The Politics of Middle Class Indonesia, Clayton, Australia: Centre for Southeast Asian Studies, 1990.

Liow, Joseph Chinyong, Piety and Politics. Islamism in Contemporary Malaysia, Oxford: Oxford University Press, 2009.

Lukens-Bull, Ronald, "Commodification of Religion and the 'Religification' of Commodities," in Pattana Kitiarsa (ed.), Religious Commodifications in Asia: Marketing Goods, London and New York: Routledge, 2008.

Mahasin, Aswab, "The Santri Middle Class: An Insider's View," in Richard Tanter and Kenneth Young, eds, The Politics of Middle Class Indonesia, Clayton, Australia: Centre for Southeast Asian Studies, 1990.

Mahmood, Saba, Politics of Piety: The Islamic Revival and the Feminist Subjects, Princeton and Oxford: Princeton University Press, 2005.

Miller, Vincent J., Consuming Religion: Christian Faith and Practice in a Consumer Culture, New York: Continuum, 2004.

Nast, Seyyed Vali Reza, Islamic Leviathan. Islam and the Making of State Power, Oxford: Oxford University Press, 2001.

----, “The Rise of 'Muslim Democracy'.” Journal of Democracy 16, 2, 2005. 
Nordholt, Henk Schulte and Gerry van Klinken, "Introduction”, in Henk Schulte Nordholt and Gerry van Klinken (ed.), Renegotiating Boundaries Local Politics in Post-Subarto Indonesia, Leiden: KITLV Press, 2007.

Pratikno, "Local Autonomy and Democracy in Indonesia, 1999-2001," in Maribeth Erb, Priyambudi Sulistiyanto and Carole Faucher (eds.), Religionalism in Post-Subarto Indonesia, London and New York: Routledge, 2005.

Priyambudi Sulistiyanto and Maribeth Erb, "Introduction: Entangled Politics in post-Suharto Indonesia," in Maribeth Erb, Priyambudi Sulistiyanto and Carole Faucher (eds.), Religionalism in Post-Subarto Indonesia, London and New York: Routledge, 2005.

Regional Development Planning Board of Kebumen, Kebumen dalam Angka 2006, Kebumen: Bappeda, 2006.

Regional Development Planning Board, Kabupaten Banjar Dalam Angka 2006, Martapura: Pemkab Banjar, 2006.

Rodan, Garry, "Theorising political Opposition in East and Southeast Asia," in Garry Rodan (ed.), Political Oppositions in Industrializing Asia, London and New York: Routledge, 1996.

Salvatore, Armando, "The Genesis and Evolution of 'Islamic Publicness' under Global Constraints," Journal of A rabic, Islamic and Middle Eastern Studies 3, 1, 1996.

---- and Dale Eickelman, "Public Islam and the Common Good," in Armando Salvatore and Dale F. Eickleman (eds.), Public Islam and the Common Good, Leiden, Boston: Brill, 2004.

Samson, Allan, Islam and Politics in Indonesia, Berkeley: University of California Press, 1972.

Saravanamuttu, Johan, "In There a Politics of the Malaysian Middle Class? in Abdul Rahman Embong, ed., Southeast Asian Middle Classes. Prospects for Social Change and Democratisation, Bangi: UKM Press, 2001.

Smith-Hefner, Nancy J., "Javanese Women and the Veil in Post-Soeharto Indonesia," Journal of Asian Studies 66, 2, 2007.

Sulistiyanto, Priyambudi and Maribeth Erb, "Indonesian and the Quest for Democracy," in Maribeth Erb and Priyambudi Sulistiyanto (eds.), Deepening Democracy in Indonesia? Direct Elections for Local Leaders 
(Pilkada), Singapore: ISEAS, 2009.

Sulistiyono, Singgih Tri, Pemberontakan Angkatan Umat Islam (AUI) di Kebumen 1950, Semarang: Mimbar, 2000.

Turner, Bryan S., "Preface," in Parci Falk, The Consuming Body, London: Sage Publications, 1994.

Wahid, Abdurrahman, "Indonesia's Muslim Middle Class: An Imperative or a Choice?" in Richard Tanter and Kenneth Young (eds.), The Politics of Middle Class Indonesia, Clayton, Australia: Centre for Southeast Asian Studies, 1990.

White, Jenny B., "The End of Islamism? Turkey's Muslimhood Model," in Robert W. Hefner (ed.), Remaking Muslim Politics, Princeton, NJ.: Princeton University Press, 2005.

Young, Ken, "Consumption, Social Differentiation and Self-Definition of the New Rich," in Michael Pinches (ed.), Culture and Privilege in Capitalist Asia, London: Routledge, 1999.

\section{Interview}

Interview with Ahmad Rabbani, staff at the Regional Development Planning Board of the Banjar regency.

Interview with Anang Armawan, former bupati candidate, Martapura, 10 February 2008.

Interview with Bambang Purwanto, Islamic teacher and staff at the Regional Department of Religious Affairs in Kebumen, Kebumen, 16 October 2007.

Interview with Dawamuddin Masdar, an NU leader in Kebumen, Kebumen, 9 January 2008.

Interview with Dede Hidayatullah, civil servant who also resides in Sekumpul, 22 February 2008.

Interview with Fauzan Saleh, the Chairman of the Executive Council of NU branch in Martapura, 13 February 2008.

Interview with Ibnu Ashari, 14 January 2008.

Interview with Ismail Morsade, Martapura, 20 January 2008.

Interview with Khairul Saleh, the Regent of Banjar, Martapura, 21 February 2008. 
Interview with Mashuri, former chief of the social office and now of the economic office at the Banjar regency, 16 February 2008.

Interview with Masnur Manurung, a Christian woman civil servant in the Banjar regional administration office, 12 February 2008.

Interview with Mawardi Abbas, Martapura, 16 February 2008.

Interview with Muhammad Dahsyad, a member of the Education Council of Muhammadiyah in Kebumen, and Muhammad Abduh Hisyam, the Secretary of Muhammadiyah in Kebumen, 12 October 2007.

Interview with Muhammad Yunus and Abdullah Munir, the Chairman of al-Iman Foundation and the Headmaster of SDIT al-Madinah respectively, Kebumen, 17 October 2007.

Interview with Nafsiah, religious figure who resides in Sekumpul Neighborhood, 11 February 2008.

Interview with Nurhadi, member of Nadzir Darussalam Mosque, 17 March 2008.

Interview with Ridwan, Former Director Al Zahra, 17 February 2008.

Interview with Rizki Wijayakusuma, Ahmad Diauddin and Suriani, admin staff of Al-Zahra, 19 February 2008.

Interview with Rizki Wijayakusuma, former NGO activist, Martapura, 19 February 2008.

Interview with Yazid Machfudz, 7 November 2007. 
Noorhaidi Hasan 